\title{
Inward Rectification in Response to FMRFamide in Aplysia Neuron L2: Summation with Transient K Current
}

\author{
Stuart Thompson and Peter Ruben ${ }^{a}$ \\ The Hopkins Marine Station of Stanford University, Pacific Grove, California 93950
}

The response of Aplysia abdominal ganglion neuron L2 to the molluscan neuroactive peptide Phe-Met-Arg-Phe- $\mathrm{NH}_{2}$ (FMRFamide) was studied in voltage-clamp experiments. In all of the experiments, focal application of the peptide to the soma activated an inward rectifier current and reduced the apparent amplitude of the transient $K$ current, $I_{A}$. In a few cells, $\mathrm{Na}$ and $\mathrm{K}$ currents were activated in addition to these effects. Voltage-jump experiments were performed to study the ionic dependence, kinetics, and voltage dependence of the inward rectifier. Inward rectification increased exponentially during hyperpolarizing pulses and recovered exponentially on return to the resting potential. The reversal potential was variable, but was near $-\mathbf{4 0} \mathrm{mV}$ at the beginning of experiments. Inward rectification was insensitive to changes in external $\mathrm{Na}, \mathrm{Ca}$, or $\mathrm{K}$ concentration, but lowering the external $\mathrm{Cl}$ concentration had complicated effects on current amplitude. When $\mathrm{KCl}$ microelectrodes were used, perfusion with low- $\mathrm{Cl}$ external saline increased the amplitude of the peptide-dependent inward rectifier and shifted its reversal potential to a more positive voltage. With KAC microelectrodes, perfusion with low- $\mathrm{Cl}$ saline reduced the amplitude of the current. Inward rectification increased when a KAC microelectrode was withdrawn and replaced with a low-resistance $\mathrm{KCl}$ electrode, even when there was no measurable change in reversal potential. These results suggest that the FMRFamide-dependent inward rectifier is a $\mathrm{Cl}$ current that, like the current described by Chesnoy-Marchais (1982, 1983), is modulated by intracellular $\mathrm{Cl}$.

FMRFamide reduced the apparent amplitude of $I_{A}$ without affecting the voltage dependence of $I_{A}$ activation or inactivation. The reduction in $I_{A}$ followed the same time course as the change in inward rectification after peptide application, but there was no evidence for a direct effect of FMRFamide on $I_{A}$. Instead, the decrease appears to result from summation of $I_{A}$ with the inward tail current due to the decay of the peptide-dependent inward rectifier during depolarization.

\footnotetext{
Received June 16, 1987; revised Oct. 5, 1987; accepted Jan. 6, 1988.

We thank I. B. Levitan for helpful discussions and D. Lotshaw and I. B. Levitan for sharing a preprint of their work. This research was conducted at the Hopkins Marine Station and we thank the staff of that institution and S. Nugent for assistance. Support was provided by PHS Grant NS14519 to S.T. and by a grant from the Alberta Heritage Foundation for Medical Research to P.R.

Correspondence should be addressed to Stuart Thompson at the above address.

a Present address: Bekesey Laboratory of Neurobiology, University of Hawaii, Honolulu, HI 96822 .

Copyright (C) 1988 Society for Neuroscience $0270-6474 / 88 / 093200-08 \$ 02.00 / 0$
}

The neuroactive peptide Phe-Met-Arg-Phe- $\mathrm{NH}_{2}$ (FMRFamide) elicits a variety of responses in molluscan neurons. In different cells it can activate $\mathrm{Na}$ currents or $\mathrm{K}$ currents, decrease $\mathrm{Ca}$ currents, or depress the amplitude of voltage-dependent and Ca-dependent K currents (Cottrell, 1982; Cottrell et al., 1984; Colombaioni et al., 1985; Ruben et al., 1986; Brezina et al., 1987a, b; Cottrell and Davies, 1987). We found that FMRFamide has a novel effect on neuron L2 in the Aplysia abdominal ganglion, where it activates a $\mathrm{Cl}$ inward rectifier. This response resembles the $\mathrm{Cl}$ current seen during hyperpolarizing pulses in Aplysia ccrcbral ganglion ncurons after intracellular $\mathrm{Cl}$ loading (Chesnoy-Marchais, 1982, 1983). In the majority of experiments on L2, FMRFamide activated only the inward rectifier, while in a few preparations, $\mathrm{Na}$ and $\mathrm{K}$ currents, like those described in Aplysia neurons L4 and L6 (Ruben et al., 1986) were also activated. In this report we concentrate on those cells expressing only an increase in inward rectification in response to the peptide.

The voltage dependence of inward rectification, and its relatively slow response to changes in voltage, produce an interesting interaction between this agonist-dependent current and the transient outward current, $I_{\mathrm{A}}$. The apparent amplitude of $I_{\mathrm{A}}$ is reduced and it may even appear to be abolished after applying FMRFamide. This report describes the properties of the FMRFamide-dependent inward rectifier and the interaction between this current and $I_{\mathrm{A}}$. A preliminary report of this work has appeared (Ruben and Thompson, 1986).

\section{Materials and Methods}

Specimens of Aplysia were obtained from Sea Life Supply (Sand City, CA) and maintained in flowing, natural seawater. The abdominal ganglion was removed and desheathed manually without enzyme treatment. Neuron L2 (Frazier et al., 1967) was axotomized by making a cut across the left side of the ganglion and undercutting the left upper-quadrant neurons with iris scissors to isolate a cluster of cells. The cell cluster was mounted in a Lucite chamber and cooled to $11-15^{\circ} \mathrm{C}$. Neuron L2 was voltage-clamped using a 2-microelectrode method (Barish and Thompson, 1983). Microelectrodes had resistances of 2-7 M $\Omega$ and were filled with $2 \mathrm{M} \mathrm{KAc}$ or $3 \mathrm{M} \mathrm{KCl}$, as indicated in the text. The chamber was held at $0 \mathrm{mV}$ by a separate voltage-clamp amplifier interfacing the bath via 2 saline-agar bridges. Membrane current was measured from the differentially recorded voltage drop across a $500 \mathrm{k} \Omega$ resistor in series with the bath-current electrode. This method provided good control over bath voltage and allowed rapid settling of membrane currents in response to voltage-clamp pulses.

The control saline had the following millimolar composition: 470 $\mathrm{NaCl}, 10 \mathrm{KCl}, 10 \mathrm{CaCl}_{2}, 50 \mathrm{MgCl}_{2}, 10 \mathrm{HEPES}$ (pH 7.8). Low-Na saline was prepared by equimolar substitution of Tris- $\mathrm{Cl}$, gluconate, or $N$-methylglucamine for $\mathrm{Na}$. Low-Cl saline was prepared by substituting $\mathrm{Na}$ isothionate for $\mathrm{NaCl}$ ( $\mathrm{pH}$ adjusted to 7.8) to yield a final $\mathrm{Cl}$ concentration of $130 \mathrm{~mm}$, compared to the control concentration of $550 \mathrm{~mm}$. Perfusion with low-Cl saline caused a change in the junction potential at the voltage electrode of the bath-voltage clamp. The magnitude of the change 
was estimated by recording the bath voltage with a separate, low-resistance calomel electrode immersed in a saturated $\mathrm{KCl}$ solution and interfaced to the bath via a thin, porous porcelain plug that allowed $\mathrm{KCl}$ to wccp slowly out of the electrode. The bath-voltage clamp was given a zero $\mathrm{mV}$ command while the solution was changed from control to low-Cl saline. After introducing the low-Cl saline, the calomel electrode reported a stable $-4 \mathrm{mV}$ shift in potential. Voltage-clamp command pulses were adjusted to correct for this change during perfusion with low-Cl saline. Even without correction, a voltage error of this magnitude would have little effect on the conclusions drawn from this study.

A stock soltuion of $10 \mathrm{~mm}$ FMRFamide (Sigma) was prepared in distilled water and frozen until use. Peptide was applied to the cell body by a pressure pulse (20-65 psi; duration, $20-700 \mathrm{msec}$ ) from a micropipette containing $10 \mu \mathrm{M}$ FMRFamide diluted in the appropriate external saline. The micropipette was postioned as close as possible to the cell without actually penetrating it. Close positioning was important to insure focal application of peptide to the soma without exposing other ccll bodies or presynaptic terminals in the cell cluster. In some experiments, the bath was continuously perfused, while in others, it was flushed with 10 volumes of saline between peptide applications. These procedures were necessary to minimize desensitization of the peptide response.

Records of membrane voltage and current were stored on a laboratory computer (DEC 11/23), FM magnetic tape (Tanburg/Sangamo), or chart recorder (Gould/Brush 220). Tape and chart records were digitized before analysis. In quantifying the kinetics of currents, we used a nonlinear least-squares method to find the best fit between specified theoretical curves and the measured data points (algorithm of Marquardt, 1963, as described by Bevington, 1969). Computed curves were displayed along with the data points on the terminal to allow the accuracy of the fitting procedure to be verified by inspection.

\section{Results}

FMRFamide elicits 2 kinds of responses in Aplysia neuron L2. Figure 1 shows examples of membrane currents in different preparations in response to brief application of the peptide to the cell body at a holding voltage of $-40 \mathrm{mV}$. In Figure $1 A$, the peptide activates an inward current that begins after a short delay, peaks in $6 \mathrm{sec}$, and recovers within $30 \mathrm{sec}$ (recovery time in different preparations, $20-230 \mathrm{sec}$ ). This appears to be a single-component response that results from an increase in inward rectification, as described below. Figure $1 B$ shows a different, multicomponent response in L2 in another preparation. This response consists of an inward current followed by a slowly developing outward current, and resembles the effect of FMRFamide on Aplysia neurons L4 and L6 (Ruben et al., 1986). The peptide response in $\mathrm{L} 6$ is shown in Figure $1 C$ for comparison. The multicomponent response in $\mathrm{L} 2$ results from the activation of $\mathrm{Na}$ and $\mathrm{K}$ currents, in addition to the inward rectifier. It differs from the response in $\mathrm{L} 4$ and $\mathrm{L} 6$ because the peptide does not activate inward rectification in those cells (Ruben et al., 1986). The source of the variability in the response to FMRFamide in L2 is not known. It does not appear to result from differences in the spatial distributions of different FMRFamide receptor types because similar responses were obtained when the delivery pipette was moved to several locations on the cell body. In the majority of cells, single-component responses like that in Figure $1 A$ were observed, and in this report we consider only those preparations.

Figure 2 shows membrane currents in L2 during a series of hyperpolarizing voltage pulses before and after application of FMRFamide. In the control (Fig. 2A), the hyperpolarizing pulses result in nearly square steps of inward current. FMRFamide was applied focally to the soma, and the pulses were repeated at the peak of the peptide response (Fig. $2 B$ ). Figure $2 C$ shows difference currents made by subtracting the control current from the current in FMRFamide at each voltage. The peptide acti-

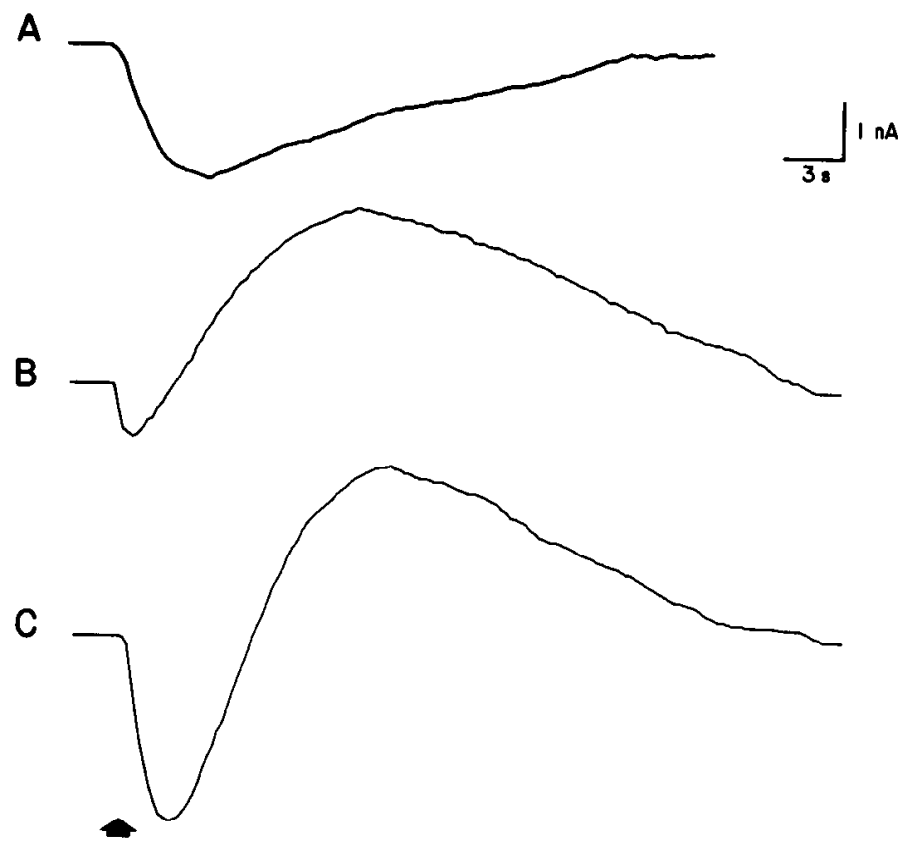

Figure 1. Membrane currents in response to FMRFamide in Aplysia neurons L 2 and L6. The peptide was applied focally to the cell body by a short pressure pulse ( $40 \mathrm{psi}, 60 \mathrm{msec}$ ) from a micropipette containing $10 \mu \mathrm{M}$ FMRFamide in control saline. The time of application is indicated by the arrow. Currents were recorded at a holding voltage of -40 $\mathrm{mV}$. $A$, Single-component, inward response in L2. $B$, Multicomponent response in $\mathrm{L} 2$ in a different preparation. $C$, Multicomponent response in L6. Current and voltage electrodes were filled with $3 \mathrm{M} \mathrm{KCl}$.

vates a voltage-dependent inward rectifier that increases in amplitude with hyperpolarization and has both a rapid, nearly instantaneous component and a time-dependent component. The simplest interpretation of these data is that the instantaneous component represents current activated by the peptide at $-40 \mathrm{mV}$, while the slow increase represents voltage-dependent activation of additional current during hyperpolarization. On returning to $-40 \mathrm{mV}$ after the hyperpolarizing pulses, inward tail currents are seen. The tail currents show that inward rectification results from an increased conductance to ions with a reversal potential more positive than $-40 \mathrm{mV}$; the tail currents result from the slow decline of that conductance on returning to the resting potential.

\section{Voltage dependence of inward rectification}

The voltage dependence of peptide-dependent inward rcctifcation was measured in the following way: The cell was held at $-35 \mathrm{mV}$ and currents were recorded during a series of $500 \mathrm{msec}$ pulses to voltages between -45 and $-110 \mathrm{mV}$ in control saline and at the peak of the response to FMRFamide. The amplitudes of the currents were plotted against pulse voltage to produce the $I(\mathrm{~V})$ curves in Figure $3 A$. The open circles show the control $I(\mathrm{~V})$ curve. Two $I(\mathrm{~V})$ curves were obtained during the peptide response; the first represents the current measured $10 \mathrm{msec}$ after beginning the pulse and approximates the instantaneous $I(V)$ curve (squares), and the other represents the steady-state current measured after $500 \mathrm{msec}$ (filled circles). The $I(\mathrm{~V})$ curves in Figure $3 A$ show that inward rectification is increased by FMRFamide.

Difference $I(\mathrm{~V})$ curves illustrating the voltage dependence of the inward rectifier were made by subtracting the control $I(\mathrm{~V})$ 
Figure 2. Membrane currents in L2 during hyperpolarizing voltage pulses in control saline and after focal application of FMRFamide to the soma. $\mathrm{KCl}$ electrodes were used throughout. The cell was held at $-40 \mathrm{mV}$ and a series of pulses to voltages between -50 and $-100 \mathrm{mV}$ (increasing in $10 \mathrm{mV}$ steps) was applied. $A$, Control currents. $B$, Currents recorded during the same series of pulses at the peak of the peptide response. $C$, Differences currents illustrating the properties of the FMRFamide-dependent inward rectifier obtained by subtracting the currents in $A$ from those in $B$.

A

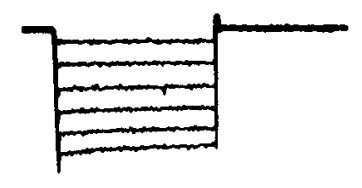

B

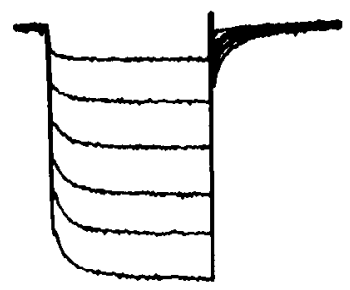

C

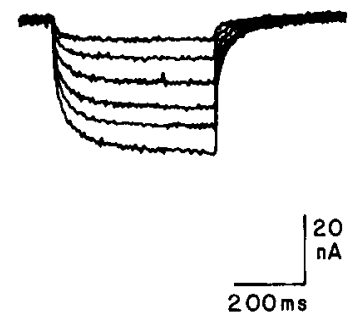

curve from the curves measured after peptide application (Fig. $3 B)$. The difference $I(\mathrm{~V})$ curve at $10 \mathrm{msec}$ (squares) is nearly linear over most of the voltage range. Extrapolation of this curve provides an estimate of the reversal potential for inward rectification that has an average value of $-38 \pm 8 \mathrm{mV}(n=11)$ in control saline at the beginning of experiments using $\mathrm{KCl}$ electrodes. Comparison of the early $I(\mathrm{~V})$ curve and the steadystate $I(\mathrm{~V})$ curve (filled circles) shows that peptide-dependent inward rectification increases in a time- and voltage-dependent fashion during hyperpolarization.

\section{Ionic dependence of inward rectification}

The increase in inward rectification in response to FMRFamide does not depend on $\mathrm{Na}$, $\mathrm{Ca}$, or $\mathrm{K}$ currents. Substitution of Tris, gluconate, or $N$-methylglucamine for external $\mathrm{Na}$ did not have a significant, reproducible effect on the amplitude of the peptide response. Similarly, the response was not affected by substituting $\mathrm{Mn}$, a calcium-current blocker, for $\mathrm{Ca}$ in the external saline. Several observations indicated that $\mathrm{K}$ current does not contribute significantly to the response: (1) the inward rectifier current reverses at a voltage that is more positive than the $\mathrm{K}$ equilibrium potential (about $-73 \mathrm{mV}$; Kunze et al., 1971) or the reversal potential for transient $\mathrm{K}$ current in $\mathrm{L} 2$ (range, -60 to $-67 \mathrm{mV}$ ); (2) tail currents, on returning to $-40 \mathrm{mV}$ after hyperpolarizing pulses in FMRFamide, are inward, whereas at this voltage any tail current due to $K$ is expected to be outward; (3) when $R b$, a blocker of K-dependent inward rectification (Standen and Stan- field, 1980), is substituted for external $\mathrm{K}$, the peptide response remains unchanged.

Changes in external $\mathrm{Cl}$ concentration strongly affect the amplitude of the peptide response. Figure $4 A$ shows peptide difference currents during a series of hyperpolarizing pulses recorded with $\mathrm{KCl}$ microelectrodes. FMRFamide activates an inward rectifier with an estimated reversal potential near -40 $\mathrm{mV}$ in this example. The same procedure was repeated $10 \mathrm{~min}$ after perfusing the bath with low- $\mathrm{Cl}$ saline, and the difference currents are shown in Figure $4 B$. Perfusion with low $\mathrm{Cl}$ caused a $2 \mathrm{nA}$ inward shift in the holding current at $-40 \mathrm{mV}$ that recovered gradually during continued incubation in low- $\mathrm{Cl}$ saline. The amplitude of the peptide-dependent inward rectifier increased in low- $\mathrm{Cl}$ saline, and the reversal potential was approximately $-20 \mathrm{mV}$. The change in reversal potential was close to the change expected for a $\mathrm{Cl}$ current (expected change, 23 $\mathrm{mV}$ ). This result suggests that peptide-dependent inward rectification results from the activation of a voltage-dependent $\mathrm{Cl}$ current during hyperpolarization.

A different result was obtained with potassium acetate electrodes. Figure $4 C$ shows peptide differences currents in control saline during the same series of hyperpolarizing pulses recorded with 2 м KAc microelectrodes in a different preparation. The bath was perfused with low- $\mathrm{Cl}$ saline and the pulses were repeated after a 10 min incubation. Peptide-dependent inward rectification was greatly reduced in low $\mathrm{Cl}$ (Fig. $4 D$ ) under these conditions, and the response recovered after washing with nor-
Figure 3. Current-voltage relationship of FMRFamide-dependent inward rectification. Currents were recorded during $500 \mathrm{msec}$ pulses to voltages between -45 and $-110 \mathrm{mV}$ from a holding voltage of $-35 \mathrm{mV}$. A, Open circles, $I(\mathrm{~V})$ curve in control saline. FMRFamide was applied and $2 I(\mathrm{~V})$ curves were measured at the peak of the peptide response. The 2 curves represent the current $10 \mathrm{msec}$ (squares) and $500 \mathrm{msec}$ (filled circles) after beginning each hyperpolarizing pulse. $B$, Difference $I(V)$ curves obtained by subtracting the control $I(\mathrm{~V})$ curve from the curves measured after applying FMRFamide. Squares, difference $I(\mathrm{~V})$ curve after 10 msec; filled circles, difference $I(V)$ curve after $500 \mathrm{msec}$. All of the data are from the same experiment, using $\mathrm{KCl}$ electrodes, and were obtained during a single peptide application.
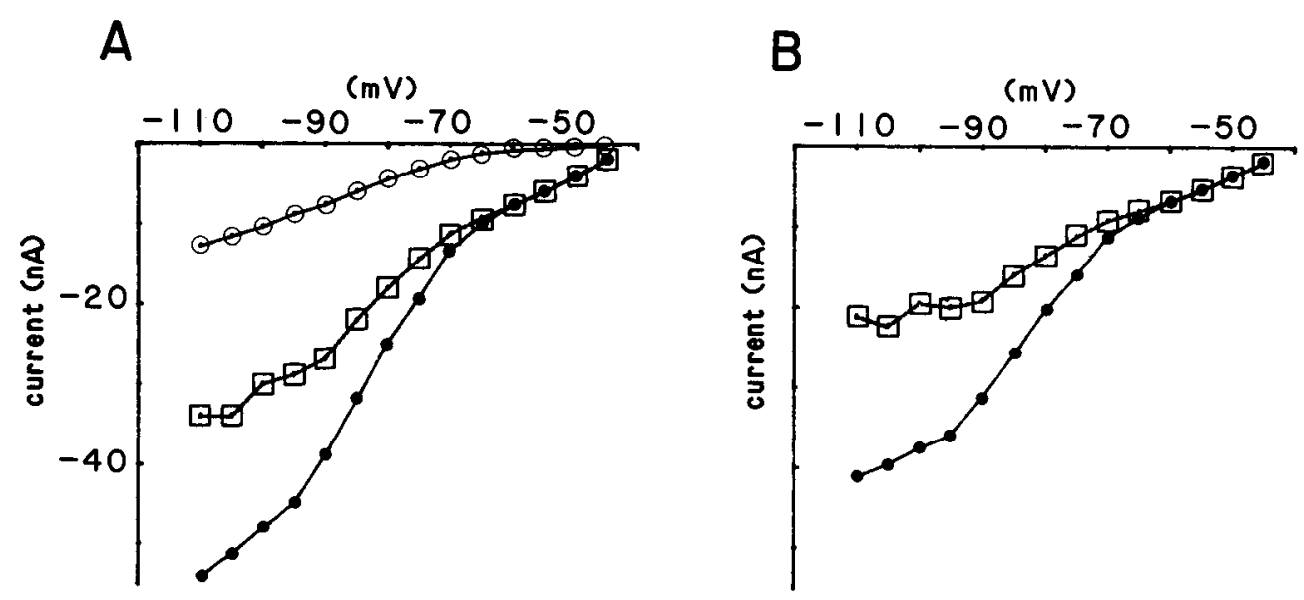
mal saline. This result is not expected if the inward rectifier is a $\mathrm{Cl}$ current and the intracellular $\mathrm{Cl}$ concentration remains constant during the external ion substitution. If it was a $\mathrm{Cl}$ current, lowering external $\mathrm{Cl}$ should shift the reversal potential to a more positive voltage and increase the current amplitude during hyperpolarization, as was seen with $\mathrm{KCl}$ electrodes. It is possible that the intracellular $\mathrm{Cl}$ concentration gradually decreases when external $\mathrm{Cl}$ is lowered and $\mathrm{KAc}$ electrodes are used. The transient inward shift in holding current that occurs during low-Cl perfusion indicates that $\mathrm{L} 2$ has a resting conductance to $\mathrm{Cl}$ that could allow the intracellular and extracellular concentrations to equilibrate. We could not measure the reversal potential in lowCl saline using KAc electrodes because of the small amplitude of the response, and were unable to test this idea directly. A decrease in intracellular $\mathrm{Cl}$ concentration could have a large effect on the peptide response if internal $\mathrm{Cl}$ is necessary for activation of the inward rectifier, as suggested by Chesnoy-Marchais $(1982,1983)$. This effect could be mitigated when $\mathrm{KCl}$ electrodes are used if the leakage of $\mathrm{Cl}$ from the electrodes is sufficient to compensate in part for the loss of internal $\mathrm{Cl}$.

The importance of intracellular $\mathrm{Cl}$ for peptide-dependent inward rectification was tested by recording peptide responses with $\mathrm{KAc}$ and $\mathrm{KCl}$ microelectrodes in the same cell. Difference currents were obtained during a series of hyperpolarizing pulses using KAc electrodes (Fig. $4 E$ ). The voltage microelectrode was then removed and replaced with a $2 \mathrm{M} \Omega, 3 \mathrm{M} \mathrm{KCl}$ electrode, while the current electrode and the FMRFamide delivery pipette were left in place. After $10 \mathrm{~min}$, the same series of hyperpolarizing pulses was repeated and difference currents were measured as before (Fig. $4 F$ ). There was no attempt to load the cell with $\mathrm{Cl}$ by iontophoresis. The difference currents were 2 times larger after introducing the $\mathrm{KCl}$ microelectrode, but there was no measurable change in the reversal potential of the current

Our interpretation of the Cl substitution and electrode replacement experiments is that FMRFamide activates a voltagedependent $\mathrm{Cl}$ current in $\mathrm{L} 2$ that increases in amplitude during hyperpolarization and decays slowly on returning to the resting potential. Like the $\mathrm{Cl}$ current described by Chesnoy-Marchais (1982, 1983), the amplitude of the FMRFamide-dependent inward rectifier appears to be very sensitive to the intracellular $\mathrm{Cl}$ concentration, more sensitive than would be expected from the change in ion driving force. This suggests that the peptidedependent current is modulated by internal $\mathrm{Cl}$ such that an increase in cytoplasmic $\mathrm{Cl}$ concentration favors voltage-dependent activation of the current.

\section{Kinetics of inward rectification}

Difference currents representing the increase in inward rectification during hyperpolarizing pulses are shown in Figure $5 A$. The solid lines in $5 A$ are exponentials fitted to the data points. Inward rectification activates exponentially during hyperpolarization, with time constants of $112 \mathrm{msec}$ at $-60 \mathrm{mV}$ (average, $130 \pm 61 \mathrm{msec} ; n=10$ ) and $54 \mathrm{msec}$ at $-90 \mathrm{mV}$ (average, 69 $\pm 25 \mathrm{msec} ; n=10$ ). The time course of decay of inward rectification on returing to the holding voltage was measured from tail currents. Tail currents recorded at $-40 \mathrm{mV}$, after a series of $500 \mathrm{msec}$ hyperpolarizing pulses in control saline, were subtracted from the tail currents recorded during the same series of pulses at the peak of the peptide response to obtain the difference tail currents in Figure $5 B$. Inward rectification decays exponentially at $-40 \mathrm{mV}$, with an average time constant of 102 $\pm 30 \mathrm{msec}$.
A

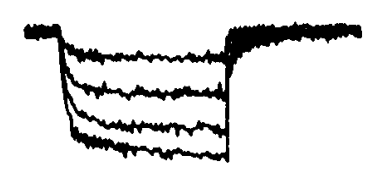

C

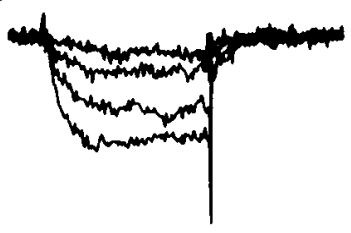

E

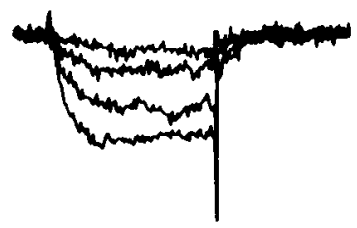

B

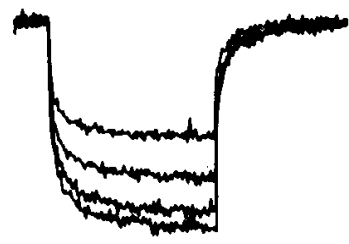

D

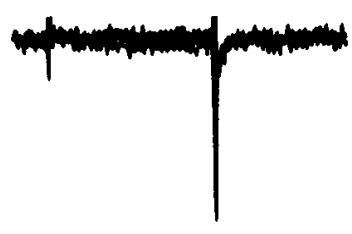

F

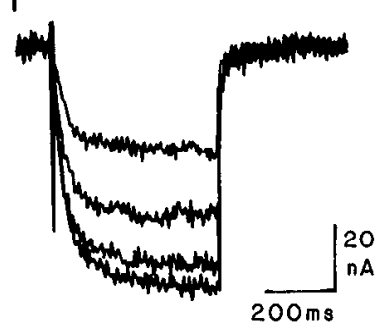

Figure 4. Peptide-dependent inward rectification is sensitive to the extracellular and intracellular $\mathrm{Cl}$ concentrations. $A-F$, Difference currents during hyperpolarizing pulses to $-70,-80,-90$, and $-100 \mathrm{mV}$ obtained by subtracting the currents in the control from the currents recorded at the peak of the response to focally applied FMRFamide. $A$, Difference currents in normal saline, recorded with $3 \mathrm{M} \mathrm{KCl}$ electrodes. $B$, Currents measured $10 \mathrm{~min}$ after perfusing the bath with low-Cl saline. The parameters of the peptide application were the same as in $A . C$, Difference currents in normal saline in a different preparation, recorded with $2 \mathrm{M}$ KAc electrodes. $D$, Currents measured $10 \mathrm{~min}$ after perfusion with low- $\mathrm{Cl}$ saline in response to the same peptide application. $E$, Difference currents in normal saline recorded with 2 м KAc electrodes. $F$, Currents measured in the same cell $10 \mathrm{~min}$ after exchanging the KAC voltage microelectrode for one containing $3 \mathrm{M} \mathrm{KCl}$. The FMRFamide delivery pipette was left in place and the parameters of the peptide application pulse were the same as in $E . C-F$ are from the same cell.

A complication arises when measuring tail currents with this method. A pulse to $-40 \mathrm{mV}$ from a hyperpolarized conditioning voltage can cause partial activation of the transient potassium current $I_{\mathrm{A}}$, which could sum with the inward rectifier tail current and obscure its time course. At this voltage, the subtraction will give the true time course of the tail current only if the pepetide has no effect on $I_{\mathrm{A}}$. The evidence suggests that this is the case, and that $I_{\mathrm{A}}$ is accurately subtracted. It was found that the time constant of the inward rectifier tail current at $-50 \mathrm{mV}$, a voltage that does not activate $I_{\mathrm{A}}$, is about the same as the time constant measured at -40 or $-30 \mathrm{mV}$, voltages at which $I_{\mathrm{A}}$ is partially activated. The simplest interpretation is that the subtraction procedure successfully separates the inward rectifier tail current from $I_{\mathrm{A}}$, but this interpretation would be invalid if the peptide had a direct effect on the potassium current.

Summation of the inward rectifier with $\mathrm{I}_{A}$ The effect of FMRFamide on the apparent amplitude of $I_{\mathrm{A}}$ is illustrated in Figure 6 . This experiment was conducted more 

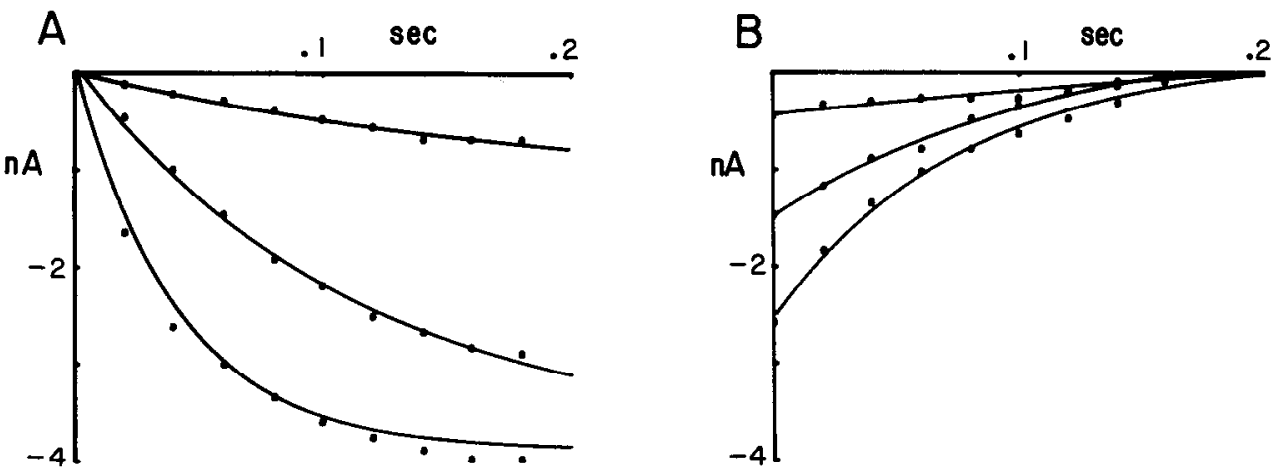

Figure 5. Kinetics of FMRFamide-dependent inward rectification. A, Activation of inward rectification during hyperpolarizing pulses to - 50, 60 , and $-80 \mathrm{mV}$ in the same cell. The pulses were applied at the peak of the response to FMRFamide. Only the time-dependent increase in inward rectification is shown, after subtracting the instantaneous current and the control current. Solid lines, single exponentials fitted to the data points by the method of least-squares. $B$. Inward rectifier tail currents in the same cell on returning to $-40 \mathrm{mV}$ after each pulse. The points show difference tail currents obtained by subtracting the control current from the current at the peak of the peptide response. Solid lines, single-exponentials fitted to the data points. $\mathrm{KCl}$ electrodes were used throughout.

than an hour after introducing 2 low-resistance $\mathrm{KCl}$ microelectrodes into the cell at a time when the reversal potential of the inward rectifier was estimated to be about $-10 \mathrm{mV}$. In Figure $6, A-D$, membrane currents are shown during test pulses to -20 $\mathrm{mV}$ from 2 conditioning voltages, -40 and $-90 \mathrm{mV}$. $I_{\mathrm{A}}$ is completely inactivated at $-40 \mathrm{mV}$, but the pulse to $-20 \mathrm{mV}$ causes partial activation of delayed outward currents (see Adams et al., 1980). At a conditioning voltage of $-90 \mathrm{mV}, I_{\mathrm{A}}$ inactivation is removed and $I_{\mathrm{A}}$ activates together with the delayed outward currents during the test pulse (trace $\mathrm{I}_{\mathrm{a}}$, Fig. $6 A$ ). The difference between the 2 records at $-20 \mathrm{mV}$ in $A-D$ represents $I_{\mathrm{A}}$. Figure $6 A$ shows control currents, while Figure $6 B$ shows the currents recorded at the peak of the response to FMRFam- ide. Figure $6, C$ and $D$, shows currents recorded during the decay of the peptide response, $45 \mathrm{sec}$ after application (Fig. $6 \mathrm{C}$ ), and after washing with normal saline (Fig. 6D). FMRFamide decreases the apparent amplitude of $I_{\mathrm{A}}$ and alters its apparent time course. These effects recover as the peptide response decays, and are reversed by washing. The decrease in $I_{\mathrm{A}}$ follows the same time course as the peptide-dependent current. This is illustrated in Figure 7, where the peak amplitude of $I_{\mathrm{A}}$ during a standard test pulse is plotted as a function of time after peptide application, together with the inward current activated by FMRFamide at a holding voltage of $-40 \mathrm{mV}$ in the same cell. The maximum decrease in $I_{\mathrm{A}}$ amplitude was scaled to the peak of the inward current to illustrate the similarity in time course.
Figure 6. Decrease in $I_{\mathrm{A}}$ after applying FMRFamide. Membrane currents were recorded during pulses to $-20 \mathrm{mV}$ from 2 conditioning voltages, -40 and -90 $\mathrm{mV} . I_{\mathrm{A}}$ is inactivated at $-40 \mathrm{mV}$, and the pulse to $-20 \mathrm{mV}$ from this voltage causes partial activation of delayed outward currents. The inactivation of $I_{\mathrm{A}}$ is removed by a $500 \mathrm{msec}$ conditioning pulse to $-90 \mathrm{mV}$, and during the subsequent pulse to $-20 \mathrm{mV}, I_{\mathrm{A}}$ activates, in addition to the delayed outward currents $\left(I_{A}\right)$. The difference between the 2 currents at $-20 \mathrm{mV}$ in $A-D$ represents $I_{\mathrm{A}} . A$, Control currents. $B$, Pairs of currents recorded at the peak of the response to FMRFamide. The inward rectifier current during the conditioning pulse to $-90 \mathrm{mV}$ is off scale. C, Pairs of currents recorded during the decline of the peptide response, $45 \mathrm{sec}$ after application. $D$, Currents recorded after washing with control saline. All the records were taken during a single peptide application. $\mathrm{KCl}$ electrodes were used throughout.

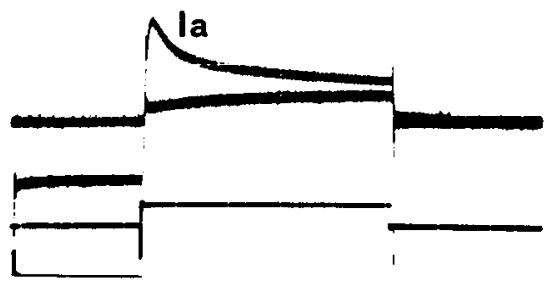

C

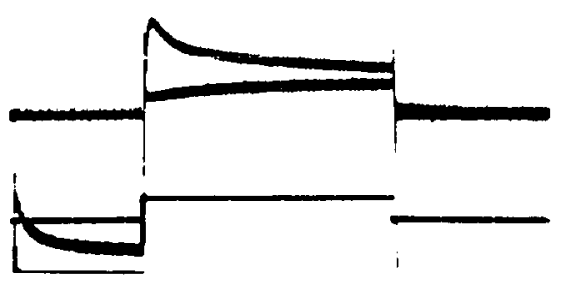

B

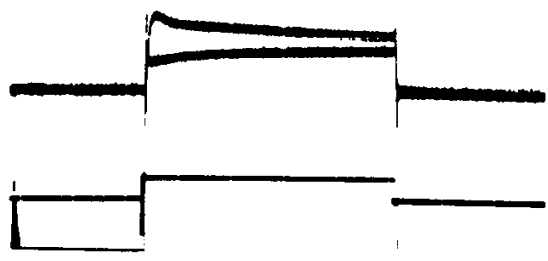

D

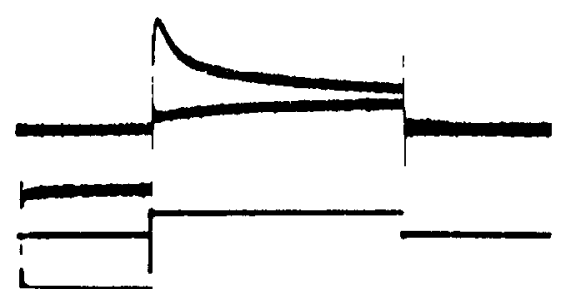


FMRFamide had no effect on the voltage dependence of $I_{\mathrm{A}}$ activation or inactivation. The $I_{\mathrm{A}}$ activation curve was measured from the peak amplitude of the current during a series of depolarizing pulses from a holding voltage of $-90 \mathrm{mV}$ under control conditions and at the peak of the peptide response. Although the apparent amplitude of $I_{\mathrm{A}}$ was reduced by peptide application, the voltage dependence of activation was not changed. The voltage dependence of $I_{\mathrm{A}}$ inactivation was measured using a prepulse method. The peak current during a test pulse to $-30 \mathrm{mV}$, minus the steady-state current at that voltage, was measured after a series of $1 \mathrm{sec}$ conditioning pulses to more negative voltages and plotted against conditioning voltage. It was found that, although the apparent amplitude of $I_{\mathrm{A}}$ was reduced by FMRFamide, the voltage dependence of $I_{\mathrm{A}}$ inactivation was not affected.

The steady-state voltage dependence of $I_{\mathrm{A}}$ inactivation in normal saline (Fig. 8, dotted line) and the voltage dependence of the FMRFamide-dependent inward rectifier (Fig. 8, solid line) are compared in Figure 8 . Both curves were normalized to a value of 1 at $-110 \mathrm{mV}$. Removal of $I_{\mathrm{A}}$ inactivation and activation of the inward rectifier both increase with hyperpolarization. The curves are somewhat different in shape, but extend over approximately the same voltage range.

During depolarizing pulses to voltages between -40 and -25 $\mathrm{mV}$ from a conditioning voltage of $-90 \mathrm{mV}, I_{\mathrm{A}}$ reaches a peak in 10-15 msec and then inactivates exponentially, with a time constant of $129 \pm 27 \mathrm{msec}(n=11)$, in normal saline. The time course of $I_{\mathrm{A}}$ is similar to that of the inward tail current in FMRFamide in this voltage range. Also, $I_{\mathrm{A}}$ and the tail current are about equal in absolute amplitude. The apparent decrease in $I_{\mathrm{A}}$ after application of FMRFamide, therefore, appears to result from summation of $I_{\mathrm{A}}$ with the inward tail current due to the decay of peptide-dependent inward rectification. There was no evidence that FMRFamide directly modulates $I_{\mathrm{A}}$.

\section{Discussion}

Several examples of the modulation of inward rectifier currents by neurotransmitters or peptides have appeared. Serotonin increases a $\mathrm{K}$ inward rectifier and decreases a $\mathrm{Cl}$ inward rectifier in Aplysia neuron R15 (Benson and Levitan, 1983; Lotshaw et al., 1986). Stanfield et al. (1985) found that substance $P$ decreases $\mathrm{K}$ inward rectification in neonatal rat neurons. In the present experiments, FMRFamide appears to activate a voltagedependent $\mathrm{Cl}$ inward rectifier in Aplysia neuron L2. This interpretation is based on the observation that the estimated reversal potential is close to the $\mathrm{Cl}$ equilibrium potential (Chesnoy-Marchais, 1982, 1983) and shifts to a more positive voltage when the external $\mathrm{Cl}$ concentration is lowered, provided that $\mathrm{KCl}$ microelectrodes are used.

The peptide-dependent inward rectifier in $\mathrm{L} 2$ has several features in common with the $\mathrm{Cl}$ current studied by Chesnoy-Marchais $(1982,1983)$ in Aplysia cerebral ganglion A cells after intracellular $\mathrm{Cl}$ injection. The 2 currents are similar in voltage dependence, and they activate and deactivate exponentially with similar kinetics. In both cases, the time constants for activation and deactivation are only weakly dependent on voltage, suggesting that the 2-state model for voltage-dependent gating presented by Chesnoy-Marchais (1983) may apply equally well to the peptide-dependent current. Also, in both cases the amplitude of the current increases when the intracellular $\mathrm{Cl}$ concentration is raised by leakage of $\mathrm{Cl}$ from a low-resistance $\mathrm{KCl}$ microelectrode. Because of these similarities, it is likely that the current

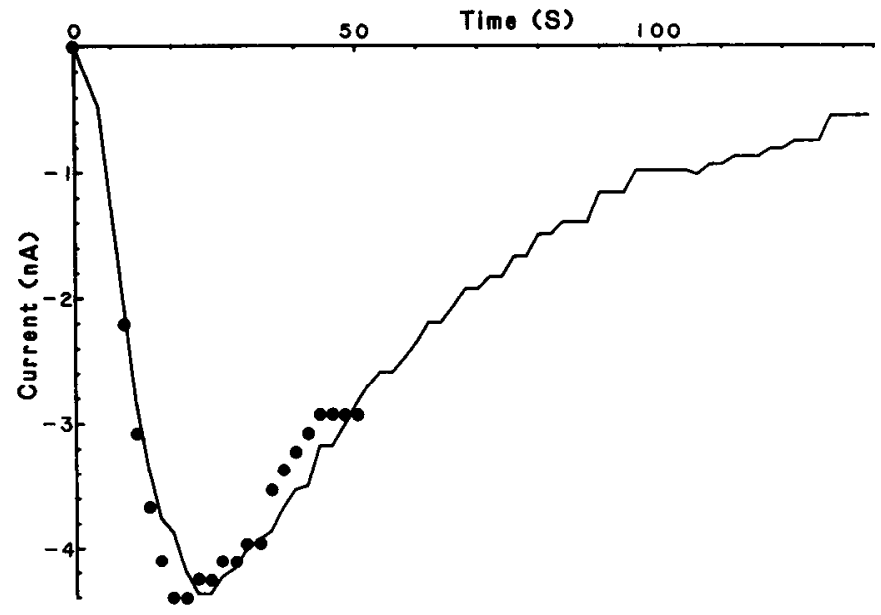

Figure 7. The decrease in $I_{\mathrm{A}}$ follows the same time course as the inward current in response to FMRFamide. FMRFamide was applied to the cell body by a $100 \mathrm{msec}$ pressure pulse ( $20 \mathrm{psi}$ ), beginning at time zero. The holding voltage was $-40 \mathrm{mV}$. Solid line, inward current in response to FMRFamide. Filled circles, peak amplitude of $I_{\mathrm{A}}$ at various times after a second, identical application of FMRFamide. $I_{\mathrm{A}}$ was activated by a pulse to $-30 \mathrm{mV}$ after a $500 \mathrm{msec}$ conditioning pulse to $-90 \mathrm{mV}$. The maximum decrease in $I_{\mathrm{A}}$ was scaled to the peak of the inward current in order to illustrate the similarity in time course. $\mathrm{KCl}$ electrodes were used throughout.

activated by FMRFamide in L2 is the same voltage-dependent Cl current that was described by Chesnoy-Marchais (1982, 1983). One important difference is that, in L2, FMRFamide is necessary for expression of the $\mathrm{Cl}$ current even when $\mathrm{KCl}$ microelectrodes are used, whereas in cerebral A cells the current is expressed after intracellular $\mathrm{Cl}$ loading without applying agonists. The $\mathrm{Cl}$ inward rectifier in Aplysia neurons also has several properties in common with $\mathrm{Cl}$ channels isolated from Torpedo electroplaques (White and Miller, 1979).

The amplitude of peptide-dependent inward rectification increases when a KAc microelectrode is replaced by a low-resistance $\mathrm{KCl}$ microclectrode, even when there is little change in reversal potential. This suggests that intracellular $\mathrm{Cl}$ may play an important role in Cl-current activation. Chesnoy-Marchais (1983) suggested that binding of $\mathrm{Cl}$ to a site associated with the channel, and accessible from the inner face of the membrane, potentiates $\mathrm{Cl}$-channel activation during hyperpolarization. The mechanism by which internal $\mathrm{Cl}$ modulates the current may be similar to the potentiation of $\mathrm{K}$ inward rectification in starfish egg by internal $\mathrm{Na}$ (Hagiwara and Yoshii, 1979), or to the effect of increased external $\mathrm{K}$ on the egg inward rectifier (Hagiwara et al., 1976; Chiani et al., 1978; Hagiwara and Yoshii, 1979).

The amplitude of the peptide-dependent current increases after perfusion with low-Cl saline when $\mathrm{KCl}$ electrodes are used, but decreases when the experiment is repeated with KAc electrodes. One possible explanation for this difference is that the intracellular $\mathrm{Cl}$ concentration gradually decreases during perfusion with low-Cl external saline in the absence of a source of internal $\mathrm{Cl}$. A small decrease in internal $\mathrm{Cl}$ could dramatically reduce the peptide response if internal $\mathrm{Cl}$ were necessary for activation. The internal $\mathrm{Cl}$ concentration does appear to be labile. Ascher et al. (1976) showed that internal $\mathrm{Cl}$ decreases in Aplysia neurons during perfusion with low-Cl external solutions, and Chesnoy-Marchais (1983) showed that the $\mathrm{Cl}$ reversal po- 
Figure 8 . Comparison of the steadystate voltage dependence of $I_{\mathrm{A}}$ inactivation (dotted line) and FMRFamidedependent inward rectification (solid line) in the same cell. The voltage dependence of $I_{\mathrm{A}}$ inactivation was measured using the prepulse method described in the text. The voltage dependence of inward rectification was determined as in Figure 5. Both curves were normalized to a value of 1 at -110 $\mathrm{mV}$.

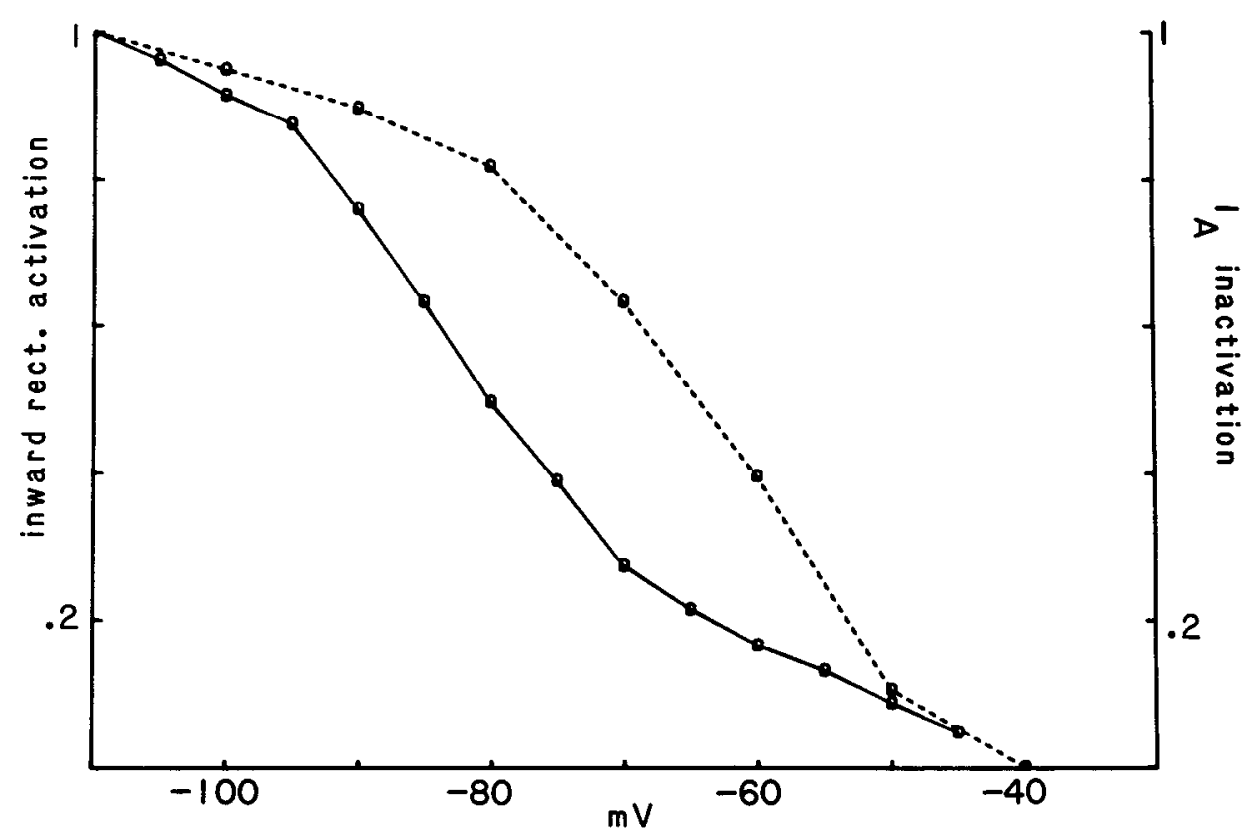

messengers and $\mathrm{G}$ proteins in the activation of FMRFamidedependent inward rectification in $\mathrm{L} 2$ has not been fully investigated, but the experiments do show that $\mathrm{Ca}$ influx is not required (see also Chesnoy-Marchias, 1983).

\section{Summation of inward rectification with $\mathbf{I}_{A}$}

The FMRFamide-dependent inward rectifier and $I_{\mathrm{A}}$ inactivation are similar in voltage dependence and kinetics in the subthreshold voltage range. During a depolarizing step to voltages between -40 and about $-25 \mathrm{mV}$ from a hyperpolarized conditioning voltage, the 2 currents are nearly equal in amplitude. The apparent decrease in $I_{\mathrm{A}}$, therefore, appears to result from summation of $I_{\mathrm{A}}$ with the inward tail current due to the decay of inward rectification during depolarization. The response to FMRFamide is well suited to influencing the excitability of L2, especially during the approach to threshold during repetitive firing. FMRFamide increases the membrane conductance and hyperpolarizes the cell away from threshold. Also, $I_{\mathrm{A}}$ is an important determinant of the repetitive firing rate (Connor and Stevens, 1971; Byrne, 1980), and summation of $I_{\mathrm{A}}$ with the inward rectifier tail current is expected to modify its influence. This interaction between an agonist-dependent current and $I_{\mathrm{A}}$ may be important to neuronal function in the subthreshold voltage range.

\section{References}

Adams D. J., S. J. Smith, and S. H. Thompson (1980) Ionic currents in molluscan soma. Annu. Rev. Neurosci. 3: 141-167.

Adams, W., and I. B. Levitan (1982) Intracellular injection of protein kinase inhibitor blocks the serotonin-induced increase in $\mathrm{K}^{+}$conductance in Aplysia neuron R15. Proc. Natl. Acad. Sci. USA 79:38773880 .

Ascher, P., D. Kunze, and T. O. Neild (1976) Chloride distribution in Aplysia neurones. J. Physiol. (Lond.) 256: 441-464.

Ascher, P., A. Marty, and T. O. Neild (1978) Life time and elementary conductance of the channels mediating the excitatory effects of acetylcholine in Aplysia neurones. J. Physiol. (Lond.) 278: 177-206.

Barish, M. E., and S. H. Thompson (1983) Calcium buffering and slow recovery kinetics of calcium-dependent outward current in molluscan neurones. J. Physiol. (Lond.) 337: 201-219.

Benson, J. A., and I. B. Levitan (1983) Serotonin increases an anom- luscan neurons, specifically the suppression of Ca current, might involve a GTP-binding protein. The role of cytoplasmic second 
alously rectifying $\mathrm{K}^{+}$current in the Aplysia neuron R15. Proc. Natl. Acad. Sci. USA 80: 3522-3525.

Bevington, P. R. (1969) Data Reduction and Error Analysis for the Physical Sciences, McGraw-Hill, New York.

Brezina, V., R. Eckert, and C. Erxleben (1987a) Modulation of potassium conductances by an endogenous neuropeptide in neurones of Aplysia californica. J. Physiol. (Lond.) 382: 267-290.

Brezina, V., R. Eckert, and C. Erxleben (1987b) Suppression of calcium current by an endogenous neuropeptide in neurones of Aplysia californica. J. Physiol. (Lond.) 388: 565-595.

Byrne, J. H. (1980) Analysis of ionic conductance mechanisms in motor cells mediating inking behavior in Aplysia california. J. Neurophysiol. 43: 630-650.

Chesnoy-Marchais, D. (1982) $\mathrm{A} \mathrm{Cl}^{-}$conductance activated by hyperpolarization in Aplysia neurones. Nature 299: 359-361.

Chesnoy-Marchais, D. (1983) Characterization of a chloride conductance activated by hyperpolarization in Aplysia neurones. J. Physiol. (Lond.) 342: 277-308.

Chiani, S., S. Krasne, S. Miyazaki, and S. Hagiwara (1978) A model for anomalous rectification: Electrochemical-potential-dependent gating of membrane channels. J. Membr. Biol. 44: 103-134.

Colombaioni, L., D. Paupardin-Tritsch, P. P. Vidal, and H. M. Gerschenfeld (1985) The neuropeptide FMRF-amide decreases both the $\mathrm{Ca}^{2+}$ conductance and a cyclic $3^{\prime}, 5^{\prime}$-adenosine monophosphatedependent $\mathrm{K}^{+}$conductance in identified molluscan neurons. J. Neurosci. 5: 2533-2538.

Connor, J. A., and C. F. Stevens (1971) Voltage clamp studies of a transient outward membrane current in gastropod neural somata. J. Physiol. (Lond.) 213: 21-30.

Cottrell, G. A. (1982) FMRF-amide neuropeptides simultaneously increase and decrease $\mathrm{K}^{+}$currents in an identified neurone. Nature 296: 87-89.

Cottrell, G. A., and N. W. Davies (1987) Multiple receptor sites for a molluscan peptide (FMRF-amide) and related peptides in Helix. J. Physiol. (Lond.) 382: 51-68.

Cottrell, G. A., N. W. Davies, and K. H. Green (1984) Multiple actions of molluscan cardioexcitatory neuropeptide and related peptides on identified Helix neurones. J. Physiol. (Lond.) 356: 315-336.

Frazier, W. T., E. R. Kandel, I. Kupfermann, R. Waziri, and R. E. Coggeshall (1967) Morphological and functional properties of iden- tified neurons in the abdominal ganglion of Aplysia california. J. Neurophysiol. 30: 1288-1351.

Hagiwara, S., and M. Yoshii (1979) Effects of internal potassium and sodium on the anomalous rectification of the starfish egg as examined by internal perfusion. J. Physiol. (Lond.) 292: 251-265.

Hagiwara, S., S. Miyazaki, and N. P. Rosenthal (1976) Potassium current and the effect of cesium on this current during anomalous rectification of the egg cell membrane of a starfish. J. Gen. Physiol. 67: 621-638.

Kunze, D. L., J. L. Walker, and H. M. Brown (1971) Potassium and chloride activities in identifiable $A$ plysia neurons. Fed. Proc. 30: 255.

Lotshaw, D. P., E. S. Levitan, and I. B. Levitan (1986) Fine tuning of neuronal electrical activity: Modulation of several ion channels by intracellular messengers in a single identified nerve cell. J. Exp. Biol. 124: 307-322.

Madison, D. V., R. C. Malenka, and R. A. Nicoll (1986) Phorbol esters block a voltage-sensitive chloride current in hippocampal pyramidal cells. Nature 321: 695-697.

Magleby, K. L., and C. F. Stevens (1972) A quantitative description of endplate currents. J. Physiol. (Lond.) 233: 173-197.

Ozeki, M., A. R. Freeman, and H. Grundfest (1966) The membrane components of crustacean neuromuscular systems. J. Gen. Physiol. 49: $1335-1349$.

Ruben, J. P., L. Girardier, and H. Grundfest (1962) The chloride permeability of crayfish muscle fibers. Biol. Bull. 123: 509-510.

Ruben, P., and S. H. Thompson (1986) FMRF-amide activation of a voltage dependent $\mathrm{Cl}$ current in Aplysia neuron L2. Soc. Neurosci. Abstr. 12: 947.

Ruben, P., J. W. Johnson, and S. Thompson (1986) Analysis of FMRFamide effects on Aplysia bursting neurons. J. Neurosci. 6: 252-259.

Standen, N. B., and P. R. Stanfield (1980) Rubidium block and ruhidium permeability of the inward rectifier of frog skeletal muscle fibers. J. Physiol. (Lond.) 304: 415-435.

Stanfield, P. R., Y. Nakajima, and K. Yamaguchi (1985) Substance P raises neuronal membrane excitability by reducing inward rectification. Nature 315: 498-501.

White, M., and C. Miller (1979) A voltage-gated anion channel from the electric organ of Torpedo californica. J. Biol. Chem. 254: 1016110166. 